\title{
Afforestation for the Provision of Multiple Ecosystem Services: A Ukrainian Case Study
}

\author{
Maria Nijnik, ${ }^{1}$ Arie Oskam, ${ }^{2}$ and Anatoliy Nijnik ${ }^{3}$ \\ ${ }^{1}$ Social, Economic and Geographical Sciences, The James Hutton Institute, Craigiebuckler, Aberdeen AB15 8QH, Scotland, UK \\ ${ }^{2}$ Agricultural Economics and Rural Policy, Wageningen University, Hollandseweg 1, 6706 KN Wageningen, The Netherlands \\ ${ }^{3}$ Environmental Network Ltd., The Hillocks, Tarland, Aboyne AB34 4TJ, Scotland, UK
}

Correspondence should be addressed to Maria Nijnik, mnijnik@hotmail.co.uk

Received 28 March 2011; Revised 21 August 2011; Accepted 30 August 2011

Academic Editor: Frits Mohren

Copyright () 2012 Maria Nijnik et al. This is an open access article distributed under the Creative Commons Attribution License, which permits unrestricted use, distribution, and reproduction in any medium, provided the original work is properly cited.

\begin{abstract}
This paper presents an economic analysis of the planting of trees on marginal lands in Ukraine for timber production, erosion prevention, and climate mitigation. A methodology combining econometric analysis, simulation modelling, and linear programming to analyse the costs and benefits of such afforestation has been adopted. The research reveals that, at discount rates lower than $2 \%$, establishment of new forests is economically justified in the majority of forestry zones. Incorporating the effects of afforestation on mitigating climate change increases social benefits. However, the results indicate that whilst soil protection benefits to agriculture from afforestation in the Steppe are expected to be high, carbon sequestration and timber production activities in the Steppe are cost inefficient due to low rates of tree growth and relatively high opportunity costs of land. The opportunity costs of land are also high in the Polissja where afforestation is cost inefficient at $2 \%$ and higher discount rates.
\end{abstract}

\section{Introduction}

Forestry is multifunctional by nature, but has traditionally been a sector of the economy whose primary objective is to maximize profits from timber production. Today, the focus of forestry is much wider, with evaluation of a broad range of ecosystem services being the mainstream in forestry economics. It is being increasingly recognised that, in addition to timber production, woodlands contribute to global carbon budgeting, provide biodiversity and aesthetic values, and serve as the basis for developing local entrepreneurial opportunities, tourism, recreation, and rural livelihoods [1]. The manifold ecosystem services do not represent a minor issue but rather are an important precondition for diverse human activities which predetermine multifunctionality of forests [2]. The relative societal weight of forestry and its manifold contribution to livelihoods are most clearly reflected in policies focusing on the development of new forests $[1,3]$. Afforestation for multiple purposes is reflected in policies of many countries [4] where multifunctional development of forestry is evidenced through institutional analyses and public opinion surveys [5] and is expressed in real terms on the ground [6].

The origin of discussions on "what forest's multifunctionality is" and "how to manage forests for multiple purposes" goes back to the 1940s. An important question is whether multifunctionality should be considered in the vertical sense, with each lot of land or forest stand fulfilling two or more functions, or whether the term should be used to describe a pattern of diversity in the horizontal sense, in which different areas are dedicated to different functions. Dana implied [7] a vertical interpretation of multifunctionality, while Pearson's view [8] was horizontal: "effective multiple use is merely organized and coordinated specialization." The vertical vision of multifunctionality seemed to be dominant in the last part of the 20th century, although the horizontal interpretation also had its advocates [9]. Bowes and Krutilla [10], for example, argue that forestry is capable of producing successfully a long list of outputs, many of which are complementary in production, whereas Sedjo questions [11] whether there is a role for specialization in multifunctional forest management. 
In the current paper, forest multifunctionality is considered in the vertical sense [7]. Characterised in this way, multifunctionality is seen as an economic concept, capturing the multiple processes taking place in forests, and shifting the emphasis of forestry away from maximising production of material (commodity) goods towards its broader objectives, that is, the provision of environmental services (erosion alleviation and climate change mitigation). Climate change, changing socioeconomic conditions, and fragile ecosystem stability have resulted in a need for a more enlarged and continuous forest cover in countries like Ukraine [12] and in new, adaptive approaches to forest management $[13,14]$. A suite of forest management alternatives can be ranging from intensive even-aged management to close-to-nature forestry, and nonintervention systems [15]. The selection of an appropriate management system is considered to be fundamental to implementing multifunctional forestry [16]. Multifunctionality implies that the objectives of numerous forestry stakeholders are incorporated into an adaptive and participatory planning process so that ecosystem services are enhanced across the landscapes [14, 17].

Decision Support Systems (DSSs) are suitable platforms for the integration of information, models, and methods required to support complex forest management solutions including those of afforestation $[18,19]$. With its focus on North-Western Europe, the AFFOREST DSS seeks to answer on where, how, and how much to afforest in order to maximize carbon sequestration and groundwater recharge and to minimize nitrate leaching [20]. ENCOFOR gives support on where and how to afforest land in developing countries in order to combine successful greenhouse gas mitigation with poverty alleviation and environmental restoration [21]. The SimForTree DSS is designed to compare different forest management and policy scenarios at different spatial scales under changing environmental conditions, particularly climatic [22]. Large-scale scenario models incorporating economic considerations of forest creation and management are becoming available [23].

Afforestation has been widely analysed in the literature, and it is commonly considered by contemporary forestry science among the most straightforward policy measures, including those addressing climate change [24]. It is relatively cheap (cost efficient), clean (it may concurrently provide other ecosystem services), proven (many countries have the legacy of tree growing), effective in the short-term (providing almost immediate effect after the tree planting) and is a rather low labour and energy consuming strategy [25]. It can be incorporated in multifunctional forest use to simultaneously enlarge timber production and bring a variety of other benefits [26].

The purpose of afforestation entails the choice of species to be planted, as does the location, tree-growing conditions and other factors. Carbon sequestration positively correlates with the growth rates of trees; it is therefore advocated to plant the most fast-growing tree species where appropriate or to establish short rotation plantations for the purpose of climate change mitigation alone $[27,28]$. However, there is sufficient evidence that forests significantly reduce soil erosion and prevent soil run-off after heavy rains $[12,29]$.
Tree plantations are still the main providers of materials for construction and industries, and of fuel for economies and households [30]. Forests provide multiple ecosystem services, and in consideration of a more holistic approach to afforestation, a number of recent studies have a wider focus by addressing several forest functions in one instance.

Michetti and Nunes [31] analyse the role of afforestation and timber management activities in stabilizing climate. Lindner et al. [32] cover the capacity of forests to provide economic, social, and ecological services (wood production; nonwood forest products; carbon sequestration; biodiversity; recreation; protective functions) under the impacts of climatic change. The European Forestry Institute used the European Forest Information (EFISCEN) modelling approach [33] to gain insights into the effects of changing management practices in forests across 30 countries under different scenarios [34]. The need to maintain the national diversities that constitute European forestry within harmonised strategies is being recognised.

Ukrainian scientists contributed to the scenario analysis through the development of long-term predictions for their forests. Their scenarios are consistent with the projections developed at the International Institute for Applied Systems Analysis (IIASA), the Ukrainian National Agricultural University, and the Ukrainian National University of Forestry [35-37]. Numerous forestry studies support the idea that a larger forest area would be attractive in Ukraine $[36,38]$, but limited knowledge is available about the economics of creating multifunctional forests to address wider sustainability objectives.

Thus, based upon both international and national studies on multipurpose afforestation, the current paper considers the economics of tree planting in Ukraine for the provision of timber production, soil protection and carbon sequestration services. Firstly, "user" benefits of afforestation which accrue to two primary sectors of rural economy, that is, forestry and agriculture, are considered, with evaluation of the role of forests in soil protection complementing an assessment of the timber supply benefits accruing from establishment of forest plantations. The paper then defines key objectives of woodlands expansion and analyses the potential for tree planting, estimating its costs and benefits. This is followed by a pilot cost-benefit analysis (CBA) of the establishment of forest plantations: if afforestation adds to the welfare of society, it is economically sound. This is observed in some areas in Ukraine, and we discuss where and why this is the case. Finally, by considering carbon sequestration in trees under the storage policy scenario, the paper goes beyond the "user" benefits of afforestation that accrue to the forestry and agriculture sectors, linking the planting of trees in Ukraine to global climate change mitigation policy objectives.

\section{Background}

The history of establishment of forest plantations in Ukraine dates back to the 17th century; however, until the 1920s, treeplanting activities were isolated and episodic [39]. The protection of land through woodland creation was considerably hampered by economic and social conditions and then by the 


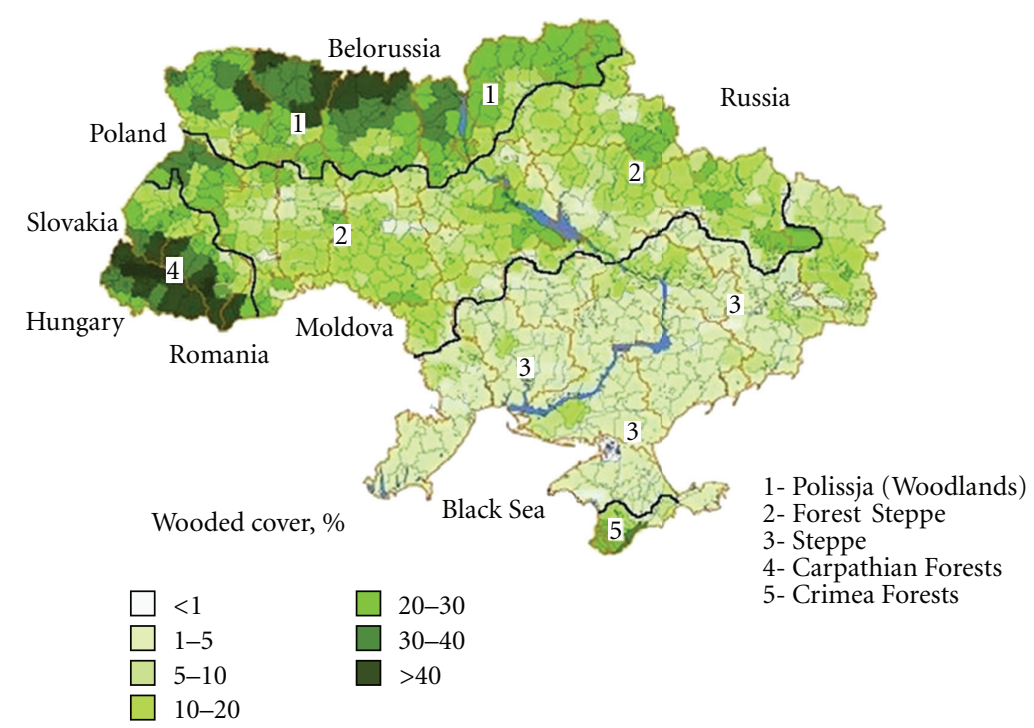

FIGURE 1: Forestry zoning of Ukraine Source: adapted from [39] and the records of the National Academy of Sciences [47].

shift in forest policy from afforestation towards natural forest regeneration. In the 1990 s, the decreasing scale of afforestation was also caused by difficulties of the transition process from a command-and-control towards a market economy, such as the lack of well-defined and ensured property rights; shortage of investment and economic incentives; increasing attention paid by forest management to short-term financial objectives [40].

Nevertheless, the reforestation coefficient remains at $94 \%$; planting on forestland amounts to about $28.5 \mathrm{kha}$; protective plantings on eroded and unproductive agricultural lands total $7 \mathrm{kha}$; shelterbelt plantings total 1.1 kha per year [36]. The necessity of afforestation is stressed in the President's Decree [41], which aimed to reform forestry in Ukraine, and in the State Programme "Forests of Ukraine, 2002-2015" [42]. Forestry legislation rests on the principle of sustainable forest management, and multiple forestry objectives are recognised by law [43].

Ukraine has good forest growing conditions and productive forests [44]. The territory was extensively covered with forests a millennium ago. Today, forest cover comprises $16.5 \%$, and this is among the lowest estimates in Europe [45]. Given that $15 \%$ of Ukraine's territory is under extreme anthropogenic pressures, and considering the role of forests for environmental quality, the development of woodlands is considered important [46]. Ukraine has a level of cultivation of $54.8 \%$ by area and faces partial erosion on $35 \%$ of its arable land. Annually, $4 \mathrm{Mt}$ of fertile soil are washed away. The damage to agriculture from erosion exceeds $8 \mathrm{M} €$ [39]. The intensity of soil erosion varies across the territory for which the annual increment of eroded land is $90 \mathrm{kha}$. According to the National Academy [47] wooded cover should increase to $20 \%$, since this would alleviate spatial spreading of erosion and its intensity.

In recent years, afforestation in Ukraine has played an important role also as a carbon dioxide reduction measure [48]. Since 2001, afforestation has become an eligible component of climate policy, meaning that over and above emissions reduction, an enhancement of GHG "sinks" and "reservoirs" via tree planting is becoming considered as increasingly important. Also, as a consequence of its afforestation and sustainable forestry strategy, Ukraine could become self-sufficient in wood and become a price setter in the European wood production. This is because the demand for wood in Europe is rising by $0.8-2.6 \%$ per year, with Europe likely to remain a high wood cost region. The potential niche for Ukraine's forestry in an international perspective is therefore its low cost of delivered wood [49].

\section{Methodology and the Results}

A methodology combining econometric analysis, simulation modeling, and linear programming for a cost-benefit analysis of afforestation has been adopted, as described in the following sections, which also present the results of the research. The modelling approach is straightforward, practical, and policy relevant. It could be easily modified, adjusted, and applied to other cases and in other countries to review evidence and the opportunities available with respect to the delivery of multiple services from land use policy decisions by assessing existing forest management options and identifying new ones.

3.1. Afforestation Potential. Afforestation potential was assessed across Ukraine's forestry zones. We developed comprehensive forestry zoning in an earlier, separate study (Figure 1) to provide a background for consideration of policy measures to enhance sustainability of forest use [39].

This spatial classification divides the territory of Ukraine into the following main forestry areas: the Polissja (Woodland), Forest Steppe, Steppe, Crimea, and the Carpathians, and further divides these main forestry areas into spatial units of lower levels of hierarchy using various factors of 
TABLE 1: Potential for afforestation by land use across zones, kha.

\begin{tabular}{|c|c|c|c|c|c|c|c|}
\hline \multirow{2}{*}{ Zones } & \multicolumn{3}{|c|}{ State forest fund } & \multicolumn{3}{|c|}{ Agricultural land } & \multirow{2}{*}{ Total } \\
\hline & Ravines & Sand & Rocky & Eroded & Deflated & Rocky & \\
\hline Polissja (Woodland) & 65.0 & 82.0 & 0.5 & 73.7 & 0.7 & 26.1 & 248.0 \\
\hline Forest Steppe & 95.0 & 84.0 & 0.6 & 451.6 & 18.3 & 61.0 & 710.5 \\
\hline Steppe & 24.0 & 64.0 & n.a. & 669.4 & 40.6 & 137.5 & 935.5 \\
\hline Carpathians & 1.6 & n.a. & 1.4 & 24.6 & n.a. & 143.4 & 171.0 \\
\hline Crimea & 0.8 & n.a. & 1.8 & 13.1 & 1.8 & 206.8 & 224.3 \\
\hline Ukraine (totally) & 186.4 & 230.0 & 4.3 & 1232.4 & 61.4 & 574.8 & 2289.3 \\
\hline
\end{tabular}

Source. Computed on the basis of data from the National Academy of Sciences of Ukraine [47].

TABLE 2: Net annual returns to current agricultural activities, $€ /$ ha.

\begin{tabular}{lccc}
\hline Forestry zone & & Forage and pasture & Wheat \\
\hline Polissja (Woodland) & Eroded and deflated land & 8.0 & 37.8 \\
\hline \multirow{3}{*}{ Forest Steppe } & Rocky land & 7.8 & n.a. \\
& Eroded land & 10.0 & 52.1 \\
& Deflated lands & 9.2 & 14.7 \\
Steppe & Rocky land & 8.0 & n.a. \\
& Eroded land & 20.0 & 61.5 \\
\hline \multirow{2}{*}{ Carpathians } & Deflated land & 6.0 & n.a. \\
& Rocky land & 7.8 & n.a. \\
Crimea & Eroded land & 7.0 & 0 \\
& Rocky land & 7.0 & 0 \\
\hline
\end{tabular}

Source. Based on the data from the National Academy of Sciences of Ukraine [28].

land use and forestry development. The land suitable for tree planting was deemed to include bare land of the "State Forest Fund" (SFF, that is, public forest estate) that is under the management of the State Committee of Forests. The land deemed suitable for afforestation also included bare and marginal agricultural land currently used for forage and pasture and some land used for wheat production for which net returns are low (Table 1).

The table shows that a total area of 2.29 Mha was initially identified as suitable for tree planting. After estimating the net present value (NPV) of afforestation, this area was reduced, to account for land in which the opportunity costs appear to be comparatively high (see below for further details). Given tree growing conditions and assumptions based on interviews with forest specialists [44], pine was considered appropriate for planting in the Steppe, Crimea and Polissja; pine and oak in the Forest Steppe; beech, fir, and/or spruce in the Carpathians.

3.2. Costs of Afforestation. The costs of afforestation of marginal and bare land in the SFF include tree-planting costs $(€ 100-200 / \mathrm{ha})$ and silvicultural expenses (€12.5-30/ha annum). These costs vary; but given that within each zone conditions are relatively stable, costs are assumed to be the same within each zone. Marginal agricultural land has alternative options to afforestation, therefore, in addition, net returns associated with current use of land were considered. Net annual returns for current wheat production were computed on the basis of land productivity data, costs of wheat production, and output prices. Estimation of costs for land used for forage and pasture was based on land productivity, and prices which agricultural enterprises pay for the equivalent cattle feed (Table 2).

Computation was in Ukraine's currency Hryvnya (which in 2007 corresponded to $0.14 €$ ). The present value (PV) costs occurring over 100 years of stipulated ages of timber harvesting were estimated at several discount rates based on [36], as seen in Table 3.

The results show that at a $4 \%$ discount rate, the PV of afforestation costs is $€ 484$ per ha on average for the country. The highest PV of costs is in the Steppe at $€ 609.5$ per ha, with the lowest, at $€ 288$ per ha, in the Carpathians. The divergence in cost estimates across zones is explained by the diversity of tree-growing and socioeconomic conditions.

3.3. Timber Supply Benefits. A sum of monetary value from additional timber yield and monetary estimates of soil protection pertaining to arable land comprise the total benefits of afforestation (when only "user benefits" to forestry and agriculture are considered). For the monetary value of timber yield changes, the model multiplies estimates of a physical crop change based on acreage in production by the price of timber [50]. This implies that timber use and prices are constant. Allowing in the long run for a stable average annual timber cut of $2 \mathrm{~m}^{3} /$ ha (ca. $50 \%$ of mean annual increment, MAI), about $4.6 \mathrm{Mm}^{3}$ of additional timber could 
TABLE 3: Afforestation costs, M€.

\begin{tabular}{lccccccc}
\hline \multirow{2}{*}{ Forestry zone } & \multicolumn{3}{c}{ Annual costs by zone } & \multicolumn{3}{c}{ PV costs } \\
& Opportunity & Planting & Care and protection & $r=0 \%$ & $r=2 \%$ & $r=4 \%$ & $r=6 \%$ \\
\hline Polissja (Wooland) & 1.4 & 16.1 & 2.0 & 356.3 & 162.7 & 99.5 & 72.7 \\
Forest Steppe & 6.4 & 32.8 & 4.1 & 1084.3 & 486.0 & 290.5 & 207.5 \\
Steppe & 14.1 & 49.8 & 7.1 & 2173.3 & 965.0 & 570.2 & 402.7 \\
Carpathians & 0.8 & 7.5 & 0.9 & 177.9 & 80.9 & 49.2 & 43.8 \\
Crimea & 0.8 & 19.6 & 2.5 & 345.0 & 159.9 & 99.4 & 73.7 \\
\hline Ukraine & 23.5 & 125.8 & 16.6 & 4136.8 & 1854.5 & 1108.8 & 792.4 \\
\hline
\end{tabular}

Source. Computed on the basis of data from the National Academy of Sciences of Ukraine [28].

TABLE 4: Estimates of the returns from timber harvesting.

\begin{tabular}{|c|c|c|c|c|c|c|c|c|}
\hline \multirow[t]{2}{*}{ Zone } & \multirow[t]{2}{*}{ Species } & \multirow[t]{2}{*}{$\begin{array}{l}\text { Stock of stands in } 100 \text { years, } \\
\qquad \mathrm{m}^{3} / \mathrm{ha}\end{array}$} & \multirow[t]{2}{*}{$\begin{array}{c}\text { Returns in the year of harvesting } \\
€ / \text { ha }\end{array}$} & \multirow{2}{*}{$\begin{array}{c}\text { PV returns } \\
€ / \text { ha, } \\
4 \% \\
\end{array}$} & \multicolumn{4}{|c|}{$\begin{array}{l}\text { PV returns by zone } \\
\text { M€ }\end{array}$} \\
\hline & & & & & $0 \%$ & $2 \%$ & $4 \%$ & $6 \%$ \\
\hline Polissja & Pine & 250 & 1250 & 24.75 & 310.0 & 42.8 & 6.1 & 0.9 \\
\hline \multirow{2}{*}{$\begin{array}{l}\text { Forest } \\
\text { Steppe }\end{array}$} & pine & 350 & 1750 & 34.65 & 612.9 & 84.6 & 12.1 & 1.8 \\
\hline & Oak & 350 & 1750 & 34.65 & 612.9 & 84.6 & 12.1 & 1.8 \\
\hline Steppe & pine & 250 & 1250 & 24.75 & 584.7 & 27.7 & 11.6 & 1.7 \\
\hline \multirow{2}{*}{$\begin{array}{l}\text { Carpa- } \\
\text { thians }\end{array}$} & beech & 350 & 1575 & 31.18 & 134.7 & 18.6 & 2.7 & 0.4 \\
\hline & fir & 400 & 2000 & 39.6 & 171.0 & 23.6 & 3.4 & 0.5 \\
\hline Ukraine & & & & & 2304.0 & 318.0 & 45.6 & 6.8 \\
\hline
\end{tabular}

be produced, bringing annual returns of $23 \mathrm{M} €$, if the stumpage value of timber is ca. $€ 5 / \mathrm{m}^{3}$ [49].

Benefits were also computed across zones over a 100year period. Table 4 shows the results when only commercial timber cut is taken into account. The following assumptions were made: stand composition in the Forest Steppe comprises $50 \%$ pine and $50 \%$ oak trees; half of the Steppe is planted with trees which would be harvested; beech stands in the Carpathians are planted on $50 \%$ of the area, as are fir stands. The Crimea, where forests play primarily a role in enhancing environmental quality, timber harvesting was not considered.

The table suggests that, at the discount rate of $0 \%, \mathrm{PV}$ returns from timber harvesting are 23.04 M€ (comparable with the annual returns of $23 \mathrm{M} €$ estimated above). The highest returns per acreage are in the Forest Steppe and the Carpathians. However, timber benefits alone do not justify tree planting in any of the zones.

3.4. Soil Protection Benefits. The notion that the scale of erosion depends on forest cover [47] was put to an empirical test by using a semilogarithmic regression (Figure 2 ). The robustness of the functional form adopted was justified, and economic attractiveness of planting trees to mitigate erosion was then assessed.

The results of the estimation show a statistically significant (at 1\% significance level) negative relationship between

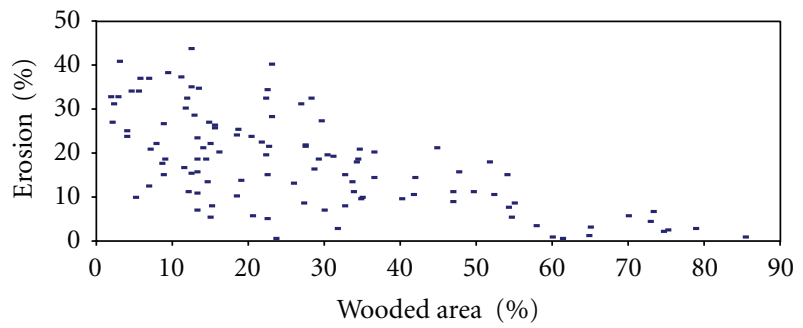

FIgURE 2: Relationship: wooded cover-erosion.

the share of eroded land $(E, \%)$ and the share of wooded land $(W, \%)$ :

$$
\begin{array}{cll}
\log (E)=3.4653-0.0329^{*} W ; & \text { or } & E=31.986 e^{-0.0329 W} \\
(29.13) \quad(-9.38) & R^{2}=0.45
\end{array}
$$

The $t$-statistic of -9.38 suggests that the negative coefficient on $W$ is significantly different from 0 , and with the increase of forest cover, the erosion rates decrease. The value of $R^{2}$ indicates that more factors influence erosion rates and there is room for improvement of the model. 
TABLE 5: Simulated rates of soil erosion.

\begin{tabular}{|c|c|c|c|c|}
\hline Wooded area $(\mathrm{W}), \%$ & Erosion (E), Ukraine, \% & Erosion (E), Carpathians, \% & Elasticity, Ukraine, \% & Elasticity, Carpathians, \% \\
\hline 0 & 32.0 & 79.1 & -1.05 & -4.13 \\
\hline 5 & 27.1 & 60.9 & -0.89 & -3.18 \\
\hline 10 & 23.0 & 46.9 & -0.76 & -2.45 \\
\hline 15 & 19.5 & 36.1 & -0.64 & -1.89 \\
\hline 20 & 16.6 & 27.8 & -0.54 & -1.45 \\
\hline 25 & 14.1 & 21.4 & -0.46 & -1.12 \\
\hline 30 & 11.9 & 16.5 & -0.39 & -0.86 \\
\hline 35 & 10.1 & 12.7 & -0.33 & -0.66 \\
\hline 40 & 8.6 & 9.8 & -0.28 & -0.51 \\
\hline 45 & 7.3 & 7.5 & -0.23 & -0.39 \\
\hline 50 & 6.2 & 5.8 & -0.20 & -0.30 \\
\hline 55 & 5.2 & 4.4 & -0.17 & -0.23 \\
\hline 60 & 4.4 & 3.4 & -0.15 & -0.18 \\
\hline 65 & 3.8 & 2.6 & -0.12 & -0.14 \\
\hline 70 & 3.2 & 2.0 & -0.11 & -0.11 \\
\hline 75 & 2.7 & 1.6 & -0.09 & -0.08 \\
\hline 80 & 2.3 & 1.2 & -0.08 & -0.06 \\
\hline 85 & 2.0 & 0.9 & -0.06 & -0.05 \\
\hline 90 & 1.7 & 0.7 & -0.05 & -0.04 \\
\hline 95 & 1.4 & 0.5 & -0.05 & -0.03 \\
\hline 100 & 1.2 & 0.4 & -0.04 & -0.02 \\
\hline
\end{tabular}

For the Carpathian Mountains, where the conditions differ substantially from elsewhere in the country (lowland), the estimated equation is as follows:

$$
\begin{aligned}
& \log (E)=4.3702-0.0523^{*} W ; \quad \text { or } \quad E=79.059 e^{-0.0523 W} \text {, } \\
& \text { (5.46) } \quad(-3.99) \quad R^{2}=0.5
\end{aligned}
$$

Simulated rates of erosion at different levels of wooded cover are shown in Table 5.

From the estimated equations, marginal changes in erosion rates relative to marginal changes in wooded cover rates are for Ukraine: $d E / d W=-0.0329 E$, and for the Carpathians: $d E / d W=-0.0523 E$. These estimations show the "elasticity" of erosion with respect to wooded cover. These results indicate that until wooded cover reaches $27 \%$ in the Carpathians and ca. 2\% in Ukraine, the erosion is elastic, that is, when wooded cover is increasing marginally, the erosion is reduced proportionally as much. This is observed up to the point when the share of eroded land is around $30 \%$ in Ukraine, and as far as it falls below $19 \%$ in the Carpathians. The results suggest that if there were no woods in rural areas the share of eroded lands would comprise $79 \%$ in the Carpathians and 32\% on average in Ukraine.

By using the results of the regression analysis, indicative estimates of the soil protection role of forests were computed. In the Polissja where wooded cover comprises ca. $26 \%$, the "elasticity" of erosion is $-0.43 \%$. This means that a $1 \%$ increase in wooded cover leads to a $0.43 \%$ decrease in erosion rates. A $1 \%$ increase of forest cover, that is, an increase of
0.029 Mha, will mitigate erosion on $0.2 \mathrm{Mha}$ of land. The net annual returns from that land were then calculated on the basis of data from Table 2 and were considered as measures of soil protection benefits to agriculture from marginal expansion of forests in the Polissja. The corresponding estimations were made for other zones, and the equation is:

$$
X=\varepsilon \cdot \frac{E}{W},
$$

where $X$ is the indicative measure of soil protection benefits to agriculture from marginal expansion of forest cover; $\varepsilon$ "elasticity" of erosion with respect to forest cover, that is, $1 \%$ increase in $W$ leads to $\varepsilon \%$ decrease in $E, \%$ (Table 5 ); $W$ share of wooded land, $\% ; E$ share of eroded agricultural land, $\%$.

Forests start providing protection benefits after the age of 5 years, and with their gradual regeneration, forests keep providing these benefits indefinitely [12]. These considerations were taken into account when computing economic estimates of the soil protection function of forestry for agriculture. The potential for forest expansion was taken from Table 1, and the assumption was made that, in nonmountainous areas, 30\% of agricultural land is used for wheat production. Given the assumptions presented above, the soil protection benefits of afforestation for agriculture are shown in Table 6 and are the highest in the Steppe.

3.5. Economic Analysis of Afforestation for Timber Production and Erosion Alleviation. The economic analysis of afforestation was carried out at various hierarchical levels. First, 
TABLE 6: Estimates of soil protection benefits to agriculture.

\begin{tabular}{lccc}
\hline Forestry zone & \multicolumn{2}{c}{$\begin{array}{c}\text { Annual average benefits, } € / \text { ha } \\
\text { Forage/pasture }\end{array}$} & $\begin{array}{c}\text { Annual benefits } \\
\text { M } € / \text { zone }\end{array}$ \\
\hline Polissja (Woodland) & 7.6 & 1.6 & 0.8 \\
Forest Steppe & 33.0 & 9.0 & 11.5 \\
Steppe & 58.2 & 17.0 & 27.5 \\
Carpathians & 0 & 9.7 & 1.7 \\
Crimea & 0 & 12.2 & 2.7 \\
\hline Ukraine & & & 44.2 \\
\hline
\end{tabular}

"user" net present value (NPV) benefits of afforestation to forestry and agriculture in Ukraine were considered. The general idea of the LP model discussed by us in detail in [44] was to consider the establishment of future forests on bare and marginal agricultural lands in Ukraine, in such a way that allows the attainment of maximum cumulative NPV of benefits from new plantations over the period of 100 years, subject to constraints. The land available for conversion into forest and tree species most suitable for growing in the particular conditions, identified earlier in the current paper, were considered, together with the following forest management regimes. The first forest management regime was a basic silviculture that is based on quick replanting of trees, after timber harvesting. The second regime was that of planting trees and the attendant silvicultural operations recommended by Ukraine forest legislation. The third regime was that of a basic silviculture, but with the timber rotation period corresponding to maximum sustainable yield.

Major constraints of this model are acreage. The model implies, for instance, that in the Carpathian Mountains, beech forests do not grow at high altitudes or that there is no land suitable for wheat production in the mountains.

The results of LP modelling provide evidence that under the assumptions and at a discount rate of $4 \%$, it is economically sound to establish monoculture plantations on the perceived bare land in the Forest Steppe $(0.28 \mathrm{Mha})$, Steppe (0.13 Mha), and the Carpathians (0.01 Mha). The shadow price of bare land $(245.2 € / \mathrm{ha})$ is highest in the Steppe. Establishment of monoculture plantations appeared to be a more economically sensible solution, with basic silviculture proven to perform better economically in all forestry zones. These results can be explained by the fact that the scope of this phase of the research was limited to user values that accrue to Ukraine's forestry and agriculture. The purpose was to form a basis for economic appraisal of practical aspects of land use management decisions. The analysis has been further extended, and in the following section, the research is presented for a higher hierarchical scale, so that in addition to "user" benefits of afforestation, carbon sequestration benefits in trees under a storage policy scenario are incorporated in the analysis.

3.6. Comparing Costs and Benefits of Afforestation. In addition to domestic gains to forestry and agriculture, afforestation provides climate change mitigation benefits. The economics of carbon sequestration forestry scenarios for
Ukraine as a stand-alone analysis is considered in Nijnik [51]. In the current paper, economic evaluation of tree planting for multiple purposes, including for carbon sequestration under the storage policy scenario, is presented. The storage policy scenario presumes a one-time planting of trees for a period of 100 years, without accounting for future use of wood and land [52]. The analysis was carried out across forestry zones with maximising of NPV of afforestation as the criterion. It determines the present value of net benefits by discounting the stream of benefits $(B)$ and costs $(C)$ back to the beginning of the base year $t=0$ :

$$
\mathrm{NPV}=\sum_{t=0}^{n} B_{t} /(1+r)^{t}-\sum_{t=0}^{n} C_{t} /(1+r)^{t} .
$$

Benefits of afforestation are expected to accrue over a long period of time, and a period of 100 years was chosen to capture most of these benefits and costs. In addition to timber production and soil protection benefits from the potential forests to alleviate soil erosion discussed earlier, the carbon $(\mathrm{C})$ uptake benefits from afforestation have been approximated using the following procedure.

The functional forms for stand growth of tree species were estimated, using the equations provided by the authors in Nijnik [53]. The coefficients of Lakida et al. [54] were used to translate the stem biomass into total above-ground biomass. The volume of stem wood was multiplied by $0.2 \mathrm{tC} / \mathrm{m}^{3}$ for its translation into carbon [55]. Carbon sequestered by the root was estimated, depending on tree species, either on the basis of the relationships presented in Van Kooten and Bulte [52] or in Lakida et al. [54]. Then, based on Nijnik $[44,51]$, the sequestered carbon was computed across zones. The price of $15 €$ per tonne of carbon was assumed to be stable and was used to calculate carbon uptake benefits based on Sandor and Skees [56]. The fact that an increase in the amount of carbon credits available to buy, especially pertaining to "hot air," is pushing the price of carbon credits down was not taken into account. The discount settings of $0 \%, 2 \%$, and $4 \%$ were applied when calculating the carbon storage option. The PV benefits from afforestation are shown in Table 7.

The results presented in Table 7 suggest that, for example, in the Polissja the highest benefits would accrue from the increased timber production and carbon uptake, whilst in the Steppe the highest benefits would accrue from the forest function of soil protection. 
TABLE 7: Afforestation benefits, PV M€.

\begin{tabular}{|c|c|c|c|c|}
\hline Forestry zone & $r \%$ & Production & Soil protection & Carbon uptake \\
\hline \multirow{3}{*}{ Polissja (Woodland) } & 0 & 310 & 84 & 362.6 \\
\hline & 2 & 42.8 & 36.2 & 49.1 \\
\hline & 4 & 6.1 & 20.6 & 6.6 \\
\hline \multirow{3}{*}{ Forest Steppe } & 0 & 1125.8 & 1150 & 1255.9 \\
\hline & 2 & 169.2 & 495.6 & 170.1 \\
\hline & 4 & 24.2 & 281.8 & 23.0 \\
\hline \multirow{3}{*}{ Steppe } & 0 & 584.7 & 2750 & 1237.4 \\
\hline & 2 & 80.7 & 1185.2 & 167.5 \\
\hline & 4 & 11.6 & 673.9 & 22.7 \\
\hline \multirow{3}{*}{ Carpathians } & 0 & 305.7 & 170 & 660.7 \\
\hline & 2 & 42.2 & 73.3 & 89.4 \\
\hline & 4 & 6.1 & 41.7 & 12.2 \\
\hline \multirow{3}{*}{ Crimea } & 0 & 0 & 270 & 437.3 \\
\hline & 2 & 0 & 116.4 & 59.2 \\
\hline & 4 & 0 & 66.2 & 8.0 \\
\hline
\end{tabular}

TABLE 8: Economic evaluation of afforestation across zones, PV M€.

\begin{tabular}{|c|c|c|c|c|}
\hline Forestry zone & $r \%$ & Total benefits & Costs & NPV \\
\hline \multirow{3}{*}{ Polissja (Woodland) } & 0 & 756.6 & 356.3 & 400.3 \\
\hline & 2 & 128.1 & 162.7 & -34.6 \\
\hline & 4 & 33.3 & 99.5 & -66.2 \\
\hline \multirow{3}{*}{ Forest Steppe } & 0 & 3531.7 & 1084.3 & 2447.4 \\
\hline & 2 & 834.7 & 486 & 348.7 \\
\hline & 4 & 329.0 & 290.5 & 38.5 \\
\hline \multirow{3}{*}{ Steppe } & 0 & 4572.1 & 2173.3 & 2398.8 \\
\hline & 2 & 1433.4 & 965 & 468.4 \\
\hline & 4 & 696.6 & 570.2 & 126.4 \\
\hline \multirow{3}{*}{ Carpathians } & 0 & 1136.4 & 177.9 & 958.5 \\
\hline & 2 & 204.9 & 80.9 & 124 \\
\hline & 4 & 59.9 & 49.2 & 10.7 \\
\hline \multirow{3}{*}{ Crimea } & 0 & 707.3 & 345 & 362.3 \\
\hline & 2 & 175.6 & 159.9 & 15.7 \\
\hline & 4 & 74.2 & 99.4 & -25.2 \\
\hline
\end{tabular}

The results vary substantially across the territory of Ukraine and depend upon the applied discount rates. The NPV of afforestation is positive in the majority of zones for discount rates of up to $2 \%$. At these discount rates, creation of multifunctional forest plantations would enlarge social benefits, including those of climate change mitigation, and would add to the welfare of society. At a discount rate of $4 \%$, the area of forest plantations would be $1.82 \mathrm{Mha}$ (excluding the Crimea and the Polissja). In the Carpathian and Crimean Mountains, commercial timber harvesting is restricted, and economic benefits from timber are therefore modest. Agricultural production is also limited in the mountainous regions. Consequently, the benefits that accrue to agriculture from the forest function of soil protection are moderate (Table 8).

\section{Conclusions}

Afforestation in Ukraine, where vast areas are currently suitable for tree planting, is seen as a means to contribute to sustainable land management and climate change mitigation. The afforestation costs are fairly low, apparently due to good forest growing conditions and relatively low labour costs. An expansion of forest cover is important for soil protection. Annually, 1 ha of forest in Ukraine provides soil protection benefits to agriculture of $€ 1.6$ to $€ 58.2$. Such a broad range can be explained by the variety of conditions. A low share of forest cover might be among the causes of erosion, and planting trees is a possible measure to alleviate this, particularly in the Steppe. When only timber production gains and gains from the protection of agricultural land against 
erosion are taken into account, at $2 \%$ through $4 \%$ discount rates, the benefits from afforestation are high in the Steppe, Forest Steppe, and the Carpathians, where the tree planting is economically justified on ca. $1.82 \mathrm{Mha}$ of land. When a discount rate of $4 \%$ is used, economic justification of tree planting would be limited to bare land in these zones, with a total area of $0.42 \mathrm{Mha}$.

The results are more positive when afforestation considerations include the rewards for climate change mitigation. But with or without consideration of carbon uptake, at discount rates lower than $2 \%$, afforestation costs are covered by the returns in the majority of regions. The results indicate that whilst soil protection benefits from afforestation in the Steppe are expected to be high, carbon sequestration and timber production activities are not cost efficient due to low rates of tree growth and relatively high opportunity costs of land. The opportunity costs of land are also high in the Polissja where afforestation is cost-inefficient at $2 \%$ and higher discount rates.

\section{Discussion}

In Ukraine, and many other former command-and-control economies (to which this study would convey), large-scale agriculture under the previous regime supported the conversion of forest or grassland to agricultural land. Currently, the decreasing agriculture [45] will likely cause the increase of abandoned land. An expansion of woodlands and, consequently, a rising role of forestry could therefore be predicted. International regulations and national programmes supporting the conversion of agricultural land back to forest focus largely on remote areas. Therefore, afforestation projects need to be incorporated in regional schemes of sustainable rural development, where socioeconomic, environmental, and climate change related components of land use changes are to be considered jointly.

In order to be viable afforestation projects need to be coherent, effective, cost efficient, widely acceptable by the public and consistent with other aspects of sustainable development policy [28]. Numerous examples indicate that climate policy measures will likely be accepted by the public and will consequently be implemented, if they are consistent with the programmes that focus on issues, other than climatic stresses [57]. Many scholars support this view, emphasising the "win-win" opportunities of forest carbon projects, which may all at once provide biodiversity conservation and rural development benefits [58]. Policy measures then should aim the "win-win" situations, which would benefit rural development, the environment, people, and the economy all together.

Afforestation for multiple purposes could enlarge total benefits and prevent potential conflicts related to the tradeoffs between biodiversity and carbon sequestration benefits or between landscape amenity values and those of carbon uptake. Although a multipurpose afforestation may result in lower rates of carbon sequestration, it is expected to be more attractive to people, because in the majority of cases it will provide additional benefits and promote sustainable rural development. A multi-purpose afforestation is often seen as a sustainable way of land reclamation and of increasing of the productivity of abandoned land $[59,60]$, whilst utilization of biomass from new plantations can provide employment opportunities and create new options for land development, being also a sustainable alternative for nuclear energy.

The potential for afforestation in Ukraine appeared to be significant. This allows us to argue that forestry activities can contribute to climate change mitigation and can provide additional social and environmental benefits by contributing to economic development in remote regions, which are most strongly affected by the transition processes. However, new insights are needed into the connection between climate policies and strategies to promote sustainable forestry and sustainable land use and sustainable rural development. Efficient and feasible forestry-based initiatives and intersectoral cooperation need to be well embedded into existing policy areas, and if flexible mechanisms are implemented, a considerable scope exists for multifunctional land use systems and "win-win" solutions.

In transition countries affected by regional socioeconomic disparities, the economic and social issues of forestry development are particularly important in view of accumulating financial assets and providing social opportunities for sustainable policy and promarket reforms. Afforestation seeks to enlarge economic gains to forestry through an enlarged wood production and to the agricultural sector, because of soil protection and hydrological forest functions. It also deemed to be beneficial in a broader sense, for example, concerning the mitigation of climate change.

The Kyoto Protocol provides opportunities for countries to cope with the changing climate from an economic perspective. Its flexible mechanisms were designed to help Annex B countries, including Ukraine, to meet their emissions reduction targets at least cost [61]. It allows (non-EU) countries like Ukraine to sell carbon offsets to industrialised countries and, therefore, raise funds needed for its forestry sector and a wider economy. Carbon sequestration through afforestation in Ukraine could be beneficial also for Annex $B$ countries in view of stabilising their collective emissions in the cheapest possible way via the trading of carbon-offset services. European investors are showing their interest to invest in afforestation projects in Ukraine. However, the potential gains from international projects are not seen as priorities for climate policies in either of these countries $[62,63]$. Therefore, unless the necessary institutional infrastructure is developed and the barriers for investment are identified and addressed, Ukraine cannot expect to benefit widely from carbon crediting.

Thus, there is a difference between the benefits of afforestation identified in this paper and the benefits for those planting the trees. Although tree planting would enlarge social gains, welfare maximisation conditions would hardly be guaranteed because of market failures. The problem: "who pays for tree planting and who receives the benefits" can scarcely be solved in Ukraine through the market and would therefore need to be regulated by government [37]. It seems that government would have to justify public 
policy concerning tree planting and balance costs and benefits to provide incentives for those planting the trees. Also, afforestation would have to be elaborated in close dialogue with stakeholders and with public involvement including in-depth consideration of various scenarios for woodlands expansion. Such deliberative processes will increase the capabilities of policy actors, assisting them in the delivery of sustainability objectives to forest management practices on the ground.

\section{Endnotes}

1. The Millennium Ecosystem Assessment [1] grouped multiple ecosystem services into supporting services, such as nutrient cycling, oxygen production, and soil formation; provisioning services of food, fibre, fuel, and water; regulating services, including climate regulation, water purification, and flood protection; cultural/social services, such as education, recreation, and aesthetic value.

2. Afforestation is an expansion of forest area on lands which more than 50 years previously contained forest but which were later converted to another use. Reforestation is a restoration of degraded or recently (within 20-50 years previously) deforested lands [64]. In this paper, these terms are considered synonymously.

3. The economics of water erosion and flooding in the Carpathians are beyond the limits of this paper. This is ongoing research, and findings on these issues will be discussed separately.

4. The economics of carbon sequestration through afforestation in Ukraine, with an assessment of the carbon storage scenario, is considered in a stand-alone paper by Nijnik [51].

5. In this paper, we seek to assess (also, in monitory terms) the biophysical potential (upper benchmark) for afforestation. In practice, however, but this is beyond the scope of this paper, tree-planting activities will be constrained by numerous economic, social, and environmental factors (e.g., land use planning; land use change and climatic change; economic and institutional development; financial considerations). Further, the potential of regulatory carbon offset trading, for example, will be limited to carbon balances, resulting from the eligible mitigation forestry projects subject to cap, as well as by the costs of GHG inventory preparation and usually high transaction costs. Also, the use of NPV criteria alone may lead to overestimation [65]. Further, in traditional forestry (where timber is the primary objective) maximising the NPV implies a comparison of the net benefits from postponing harvesting with the net benefits from harvesting timber and investing the profits. However, as shown by Nijnik [53], the maximising of NPV could promote volumes of harvesting higher than the net growth of forest stands. It follows that in search of sustainable forestry which is also to be economically efficient the establishment of fast-growing monoculture plantations would be encouraged. But this would endanger biological diversity, health, and vitality of forest ecosystems. Often also, this would enlarge costs related to care and protection of monoculture forest stands that are less stable biologically. There is a threat therefore that in the real world situation (in conditions of noninternalised externalities and market imperfections) as it would apply to monopurpose forestry, the social and environmental components of sustainability would remain undermined.

6. "Reforestation coefficient" is the share (\%) of reforested land in the total area of land previously covered with forest but that has been cut down or died (see also http:// www.ukrref.org.ua/, http://http://www.ukrndnc.org.ua http://www.bestreferat.ru/referat-160465.html for more discussion). According to the State Committee of Forestry of Ukraine annual planting in Ukraine was as follows: in 1949-1965, 100000-200000 ha, in 1966-1990, 55000-100000 ha and in 1995-2005, 35000-40000 ha per year [36].

7. These projections are based on ecological/environmental criteria, with the focus primarily on hydrological and soil protection forest functions. These forest functions are seen as the priorities in Ukraine, and the 20\% share of wooded cover is deemed to deliver a sustained ecological balance.

8. However, prospects and requirements with regard to land use changes and forest development would be case specific and varying for different end users, depending on their key objectives, and on natural and economic conditions of the location (e.g., forest and soil characteristics and level of erosion, climatic drivers, and climate mitigation strategies) and in terms of the content, scope, scale, risks, and uncertainties, dynamics and sequencing of afforestation and on the range of multiple forest ecosystem services anticipated.

9. According to the MENR [46], 1.14 Mha were to be planted with trees until the year 2010. This includes the creation of forest shelterbelts and tree planting on steep banks, sands, river, and reservoir banks, as well as on eroded and contaminated land.

10. The discount settings of $2 \%$ and $4 \%$ were kept as central in this research.

11. For example, together with the share of wooded cover, spatial distribution and the distance between fields and woods in rural landscapes play an important role in erosion mitigation, particularly in low-forested areas, but this is not taken into account in the model as it stands.

12. The figures on $W$ and $E$ are already given in percentages, thus it is not a precise computation of elasticity.

13. In this way soil protection benefits to agriculture from marginal expansion of forests were converted into monetary values. It is assumed that the protection benefits remain constant for all forest age classes over 5 years. 
14. Conversion of forest to row crops increases erosion by a factor of 20-1000 [66]. Lampietti and Dixon [67] found that the monetary value of forest function to alleviate erosion is around $\$ 30 /$ ha.

15. A substantial potential for tree planting and terrestrial carbon offsetting/trading has attracted attention of foreign investors, for example, from The Netherlands, concerning a pilot afforestation project of $5 \mathrm{kha}$ in Central, Eastern, and Western Ukraine, and a project designed to regenerate forests on lands contaminated after the Chernobyl nuclear accident (Northern part of the country, in Polissja). The creation of forests on these lands will help prevent the distribution of radioactive contamination and spreading of soil erosion [68].

\section{References}

[1] Millennium Ecosystem Assessment (MEA), Millennium Ecosystem Assessment Synthesis Report, 2005, http://maweb.org/ documents/document.356.aspx.pdf.

[2] C. Folke, J. Colding, and F. Berkes, "Synthesis: building resilience and adaptive capacity in social-ecological systems," in Navigating Social-Ecological Systems: Building Resilience for Complexity and Change, F. Berkes, J. Colding, and C. Folke, Eds., pp. 352-387, Cambridge University Press, 2003.

[3] European Commission (EC), Environmental Policy Review: Communication from the Commission to the European Parliament COM, vol. 195. Brussels, Belgium, 2007, http://www .nhlbi.nih.gov/meetings/workshops/cardiorenal-hf-hd.htm.

[4] M. Kaljonen, E. Primmer, G. De Blust, M. Nijnik, and M. Kulvik, "Multifunctionality and biodiversity conservationintitutional challenges," in Nature Conservation Management: From Idea to Practical Issues, T. Chmelievski, Ed., pp. 53-69, Helsinki-Aarhus, Lublin, Poland, 2007.

[5] M. Nijnik, L. Zahvoyska, A. Nijnik, and A. Ode, "Public evaluation of landscape content and change," Land Use Policy, vol. 26, no. 1, pp. 77-86, 2008.

[6] A. Mather, G. Hill, and M. Nijnik, "Post-productivism and rural land use: cul de sac or challenge for theorization?" Journal of Rural Studies, vol. 22, no. 4, pp. 441-455, 2006.

[7] S. T. Dana, "Multiple use, biology and economics," Journal of Forestry, vol. 41, pp. 625-627, 1943.

[8] G. A. Pearson, "Multiple use in forestry," Journal of Forestry, vol. 42, pp. 243-249, 1944.

[9] J. R. Vincent and C. S. Binkley, "Efficient multiple-use forestry may require land-use specialization," Land Economics, vol. 69, no. 4, pp. 370-376, 1993.

[10] M. D. Bowes and J. V. Krutilla, The Multiple-Use Economics of Public Forest lands: Resources for the Future, Washington, DC, USA, 1989.

[11] R. Sedjo, "Transgenic trees and trade problems on the horizon," Resources, vol. 155, pp. 9-13, 2004.

[12] S. Gensiruk and S. Ivanytsky, Forest Management and Setting up a Proper Share of Forest Cover, Lviv Publisher, L'viv, Ukraine, 1999.

[13] European Environmental Agency (EEA), "Europe's ecological backbone: recognising the true value of our mountains," EEA Report 6/2010, p. 248, Copenhagen, Denmark, 2010.

[14] L. Fazey, J. Gamarra, J. Fischer, M. Reed, L. Stringer, and M. Christie, "Adaptation strategies for reducing vulnerability to future environmental change," Frontiers in Ecology and the Environment, vol. 8, no. 8, pp. 414-422, 2010.
[15] J. Carnus, J. Parrotta, E. Brockerhoff et al., "Planted forests and biodiversity," Journal of Forestry, vol. 104, no. 2, pp. 65-77, 2006.

[16] G. Buttoud, "Multipurpose management of mountain forests: which approaches?" Forest Policy and Economics, vol. 4, no. 2, pp. 83-87, 2002.

[17] G. Weiss, "The political practice of mountain forest restoration-comparing restoration concepts in four European countries," Forest Ecology and Management, vol. 195, no. 1-2, pp. 1-13, 2004.

[18] J. G. Borges, A. Falcão, C. Miragaia, P. Marques, and M. Marques, "A decision support system for forest resources management in Portugal," in System Analysis in Forest Resources, G. J. Arthaud and T. M. Barrett, Eds., vol. 7 of Managing Forest Ecosystems, pp. 155-164, Kluwer Academic, 2003.

[19] K. M. Reynolds, M. Twery, M. J. Lexer et al., "Decision support systems in natural resource management," in Handbook on Decision Support Systems, F. Burstein and C. Holsapple, Eds., vol. 2 of International Handbooks on Information Systems Series. Handbook on Decision Support System, pp. 499-534, Springer, 2008.

[20] S. Gilliams, J. Van Orshoven, B. Muys, H. Kros, G. W. Heil, and W. Van Deursen, "AFFOREST sDSS: a metamodel based spatial decision support system for afforestation of agricultural land," New Forests, vol. 30, no. 1, pp. 33-53, 2005.

[21] L. Verchot, R. Zomer, O. Van Straaten, and B. Muys, "Implications of country-level decisions on the specification of crown cover in the definition of forests for land area eligible for afforestation and reforestation activities in the CDM," Climatic Change, vol. 81, no. 3-4, pp. 415-430, 2007.

[22] B. Muys, J. Hynynen, M. Palahi et al., "Simulation tools for decision support to adaptive forest management in Europe," Forest Systems, vol. 19, no. 1, pp. 86-99, 2011.

[23] T. Eid and K. Hobbelstad, "AVVIRK-2000: a large-scale forestry scenario, model for long-term investment, income and harvest analyses," Scandinavian Journal of Forest Research, vol. 15, no. 4, pp. 472-482, 2000.

[24] The Stern Review, “The Economic of Climate Change," 2006, http://www.icaew.com/en/library/subject-gateways/environment-and-sustainability/stern-review/.

[25] M. Nijnik, "Carbon capture and storage in forests," in Carbon Capture: Sequestration and Storage, R. E. Hester and R. M. Harrison, Eds., vol. 29 of Issues in Environmental Science and Technology, pp. 203-238, The Royal Society of Chemistry, Cambridge, UK, 2010.

[26] F. Schmithüsen, "Multifunctional forestry practices as a land use strategy to meet increasing private and public demands in modern societies," Journal of Forest Science, vol. 53, no. 6, pp. 290-298, 2007.

[27] G. C. van Kooten, Climate Change Economics, Edward Elgar, Cheltenham, UK, 2004.

[28] M. Nijnik and L. Bizikova, "Responding to the kyoto protocol through forestry: a comparison of opportunities for several countries in Europe," Forest Policy and Economics, vol. 10, no. 4, pp. 257-269, 2008.

[29] D. Anderson, "Economic aspects of afforestation and soil conservation projects," The Annals of Regional Science, vol. 21, no. 3, pp. 100-110, 1987.

[30] H. Phillips, Secure Resource Supply for the European Wood Industry, Inventory scenarios for timber resources in Ireland. COST E44 workshop, Dublin, Ireland, 2006.

[31] M. Michetti and R. Nunes, Afforestation and Timber Management Compliance Strategies in Climate Policy. A Computable 
General Equilibrium Analysis, vol. 2011.004 of FEEM Note di lavoro, 2011.

[32] M. Lindner, M. Maroschek, S. Netherer et al., "Climate change impacts, adaptive capacity, and vulnerability of European forest ecosystems," Forest Ecology and Management, vol. 259, no. 4, pp. 698-709, 2010.

[33] G. Nabuurs, R. Paivinen, and H. Schanz, "Sustainable management regimes for Europe's forests-a projection with EFISCEN until 2050," Forest Policy and Economics, vol. 3, no. 3-4, pp. 155-173, 2001.

[34] G. Nabuurs, R. Paivinen, M. J. Schelhaas et al., "Nature-oriented forest management in Europe: modeling the long-term effects," Journal of Forestry, vol. 99, no. 7, pp. 28-34, 2002.

[35] A. Shvidenko and Andrusishin, Ukraine: The Conditions and Prospects of the Forest Sector, IIASA, Laxenburg, Austria, 1998, Unpublished manuscript.

[36] State Committee of Forestry of Ukraine (SCF), State Records. Kyiv, 2007.

[37] I. Soloviy, "New forests for Europe: afforestation at the turn of century," in Proceedings of the EFI, vol. 35 of Afforestation in Ukraine-potential and restrictions, pp. 195-211, February 2000.

[38] A. Strochinskii, Y. Pozyvailo, and S. E. Jungst, "Forests and forestry in Ukraine: standing on the brink of a market economy," Journal of Forestry, vol. 99, no. 8, pp. 34-38, 2001.

[39] S. Gensiruk and M. Nijnik, Geography of Forests in Ukraine, Lviv Publisher, L'viv, Ukraine, 1995.

[40] M. Nijnik and G. C. Van Kooten, "Forestry in the Ukraine: the road ahead?" Forest Policy and Economics, vol. 1, no. 2, pp. 139-151, 2000.

[41] The President's Decree aimed to reform the forestry sector of Ukraine, 2004.

[42] The State Programme, "Forests in Ukraine, 2002-2015," Kyiv, Ukraine, 2002, http://www.rada.gov.ua.

[43] The Forest Code of Ukraine, 2006, http://zakon.rada.gov.ua/ cgi-bin/laws/anot.cgi?nreg=3852-12.

[44] M. Nijnik, To sustainability in forestry: the Ukraine's case, Ph.D. thesis, Wageningen University, 2002.

[45] FAO, Forstat, 2010, http://www.fao.org/forestry/country/en/ ukr/.

[46] Ministry of Environment and Natural Resources (MENR), “The National Report. Kyiv," 2003, http://myland.org.ua/index.php?id=\&lang=en.

[47] National Academy of Sciences (NAS), Ukraine: the Prognosis for the Development of Production Forces, Kyiv, 2002.

[48] R. Bun, M. Gusti, L. Kujii et al., "Spatial GHG inventory: analysis of uncertainty sources. A case study for Ukraine," in Accounting for Climate Change: Uncertainty in Greenhouse Gas Inventories-Verification Compliance and Trading, D. Lieberman, M. Jonas, Z. Nahorski, and S. Nilsson, Eds., pp. 63-74, Springer, Amsterdam, The Netherlands, 2007.

[49] S. Nilsson and A. Shvidenko, "The Ukrainian Forest Sector in a Global Perspective," IR-99-011/March. IIASA, Laxenburg, Austria, 1999.

[50] N. Hanley and C. Spash, Cost-Benefit Analysis and the Environment, Edward Elgar, 1993.

[51] M. Nijnik, "Economics of climate change mitigation forest policy scenarios for Ukraine," Climate Policy, vol. 4, no. 3, pp. 319-336, 2004.

[52] G. Van Kooten and E. Bulte, The Economics of Nature: Managing Biological Assets, Blackwell Publications, Oxford, UK, 2000.
[53] M. Nijnik, "To an economist's perception on sustainability in forestry-in-transition," Forest Policy and Economics, vol. 6, no. 3-4, pp. 403-413, 2004.

[54] P. Lakida, S. Nilsson, and A. Shvidenko, "Estimation of Forest Phytomass for Selected Countries of the Former European USSR," WP-95-79, IIASA, Laxenburg, Austria, 1995.

[55] A. Jessome, "Strength and related properties of woods grown in Canada. Forestry," Tech. Rep. 21, Ottawa, Canada, 1977.

[56] R. Sandor and J. Skees, "Creating a market for carbon emissions opportunities for US farmers," Choices Quarter, vol. 1, pp. 13-18, 1999.

[57] S. Huq and H. Reid, "Mainstreaming adaptation in development. IDS bulletin," Climate Change and Development, vol. 35, pp. 15-21, 2004.

[58] D. Klooster and O. Masera, "Community forest management in Mexico: carbon mitigation and biodiversity conservation through rural development," Global Environmental Change, vol. 10, no. 4, pp. 259-272, 2000.

[59] K. Naka, A. L. Hammett, and W. B. Stuart, "Forest certification: stakeholders, constraints and effects," Local Environment, vol. 5, no. 4, pp. 475-481, 2000.

[60] E. Fernandez, L. Rojo, M. N. Jimenez et al., "Afforestation improves soil fetiliyu in south-eastern Spain," European Journal of Forest Research, vol. 194, no. 4, pp. 707-717, 2010.

[61] M. Nijnik, B. Slee, and G. Pajot, "Opportunities and challenges for terrestrial carbon offsetting and marketing, with some implications for forestry in the UK," South-East European Forestry Journal, vol. 1, no. 2, pp. 69-79, 2011.

[62] S. Fankhauser and L. Lavric, "The investment climate for climate investment: joint Implementation in transition countries," Climate Policy, vol. 3, no. 4, pp. 417-434, 2003.

[63] E. Petkova and G. Faraday, "Good Practices in Policies and Measures for Climate Change Mitigation," REC and WRI, Szentendre, Hungary, 2001.

[64] IBN-DLO, Resolving Issues on Terrestrial Biospheric Sinks in the Kyoto Protocol. Dutch National Research Programme on Global Air Pollution and Climate Change, Wageningen, The Netherlands, 1999.

[65] R. N. Lubowski, A. J. Plantinga, and R. N. Stavins, "Land-use change and carbon sinks: econometric estimation of the carbon sequestration supply function," Journal of Environmental Economics and Management, vol. 51, no. 2, pp. 135-152, 2006.

[66] G. Van Kooten, Land Resource Economics and Sustainable Development. Economic Policies and the Common Good, UBC Press, Toronto, Canada, 1993.

[67] J. Lampietti and J. Dixon, To See the Forest for the Trees: A Guide to non-Timber Forest Benefits, World Bank, Washington, DC, USA, 1995.

[68] P. Lakyda, I. Buksha, and V. Pasternak, "Opportunities forfulfilling Joint Implementation projects in forestry in Ukraine," in Forest, Climate and Kyoto, vol. 222 of Unasylva, pp. 1-6, 2005. 

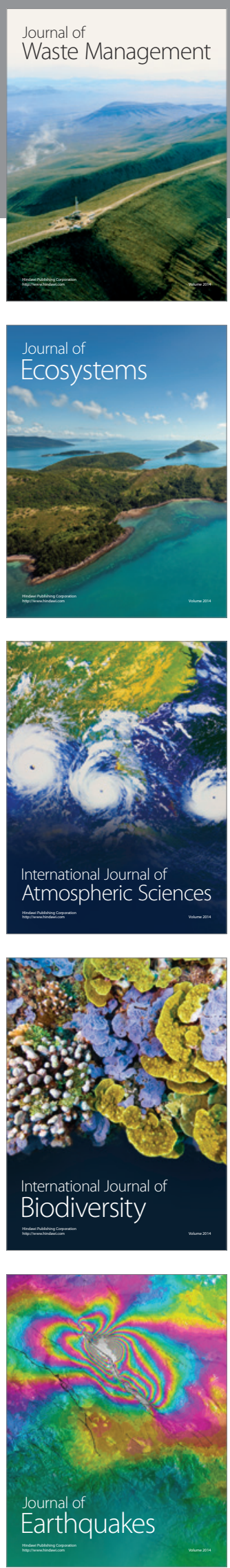
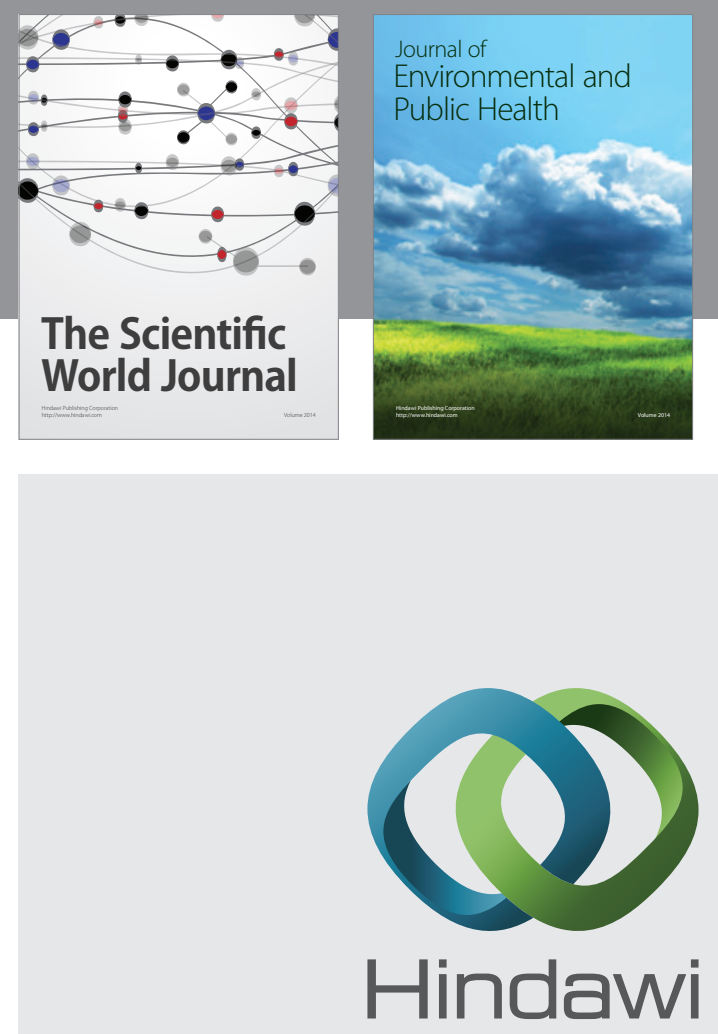

Submit your manuscripts at

http://www.hindawi.com
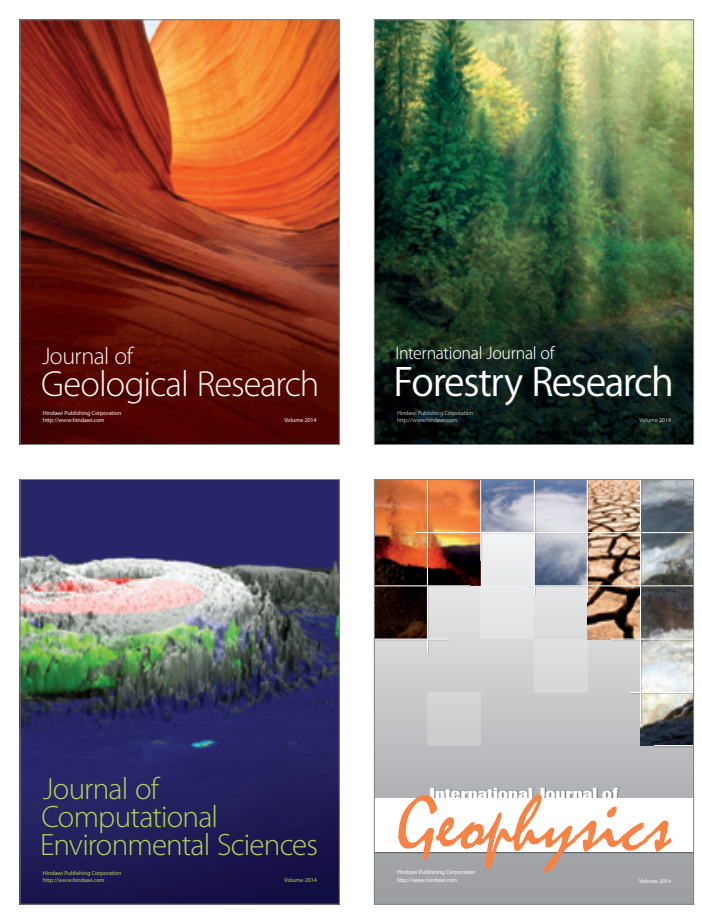
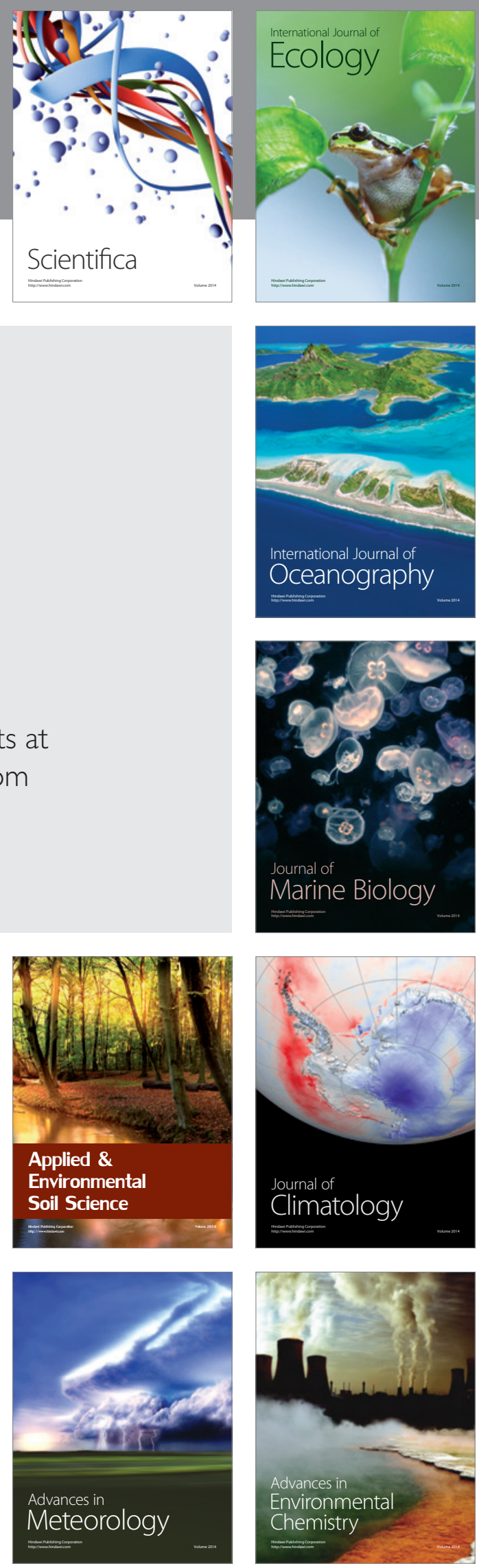